JELTL (Journal of English Language Teaching and Linguistics) e-ISSN: 2502-6062, p-ISSN: 2503-1848

2020, Vol. 5(2)

www.jeltl.org

\title{
The Graphic Organizers (GOs) in the Development of Communicative Skills in Class Presentation
}

\author{
Dedi Aprianto \\ Universitas Bumigora, Mataram, Indonesia \\ Dediaprianto44@gmail.com \\ Ikang Murapi \\ Universitas Bumigora, Mataram, Indonesia \\ Ikangmurapi11@universitasbumigora.ac.id
}

\begin{abstract}
This study aims at uncovering on how a language skill could properly be embedded to import another skill's impact. The effectiveness of GOs with patterned structures and their functions can facilitate English spoken proficiency in class presentation. In order to obtain the formulated research purpose, non-participation observation had been carried out in support with video-recording. The positive effectiveness of GOs could be varying towards certain English proficiency levels; however, the negative impacts produced by the elementary learners indicate the psychological problems and the technical problems. GOs could worthily be as recommended ELL media, since they can effectively stimulate EFL intermediate learners' intrinsic elements of learning achievement. Those therefore could effectively scaffold the intermediate learners through questioning technique in form of guided-Graphic Organizers (GOs). GOs could dynamically be incorporated into multimodal ways; by re-writing, chronological overview, and note-taking which would be employed by the upper intermediate learners. There are three situations which must be required for advanced learners; experiences-associated learning, topic-based selection, and the comprehensive understanding of GOs concepts and the topics of reading passages. Thereby, GOs can be regarded as marvelous strategies that can positively contribute to induce EFL learners' psychological achievements and effectively promote English speaking performance.
\end{abstract}

Keyword: communicative skills development, class presentation, graphic organizers (GOs)

JELTL (Journal of English Language Teaching and Linguistics), 5(2), 2020 


\section{Dedi Aprianto \& Ikang Murapi}

\section{INTRODUCTION}

Principally, reading and speaking are truly different hence their functions in different ways the language skills facilitate the EFL/ESL learners. Reading is taken account as a receptive skill, speaking is thought as a productive skill. According to Akbar (2014) reading can worthily lead to the improvement of EFL learners' speaking through engaging them in proper reading class activities and facilitating very specific reading sources where these can encourage EFL learners to reduce language learning hesitation or weaknesses to speak. Thus, it can be taken for granted as a great trigger to gear a spoken skill and reduce time in foreign language learning. As a result these are could have been termed as the integrated skills as they are close-related each other. Studying the integrated skills shows that the ESL learners do not only master the contents of the foresaid language skills, but also the strategies of EFL learning.

In order to get the better reading comprehension, a reader must have been set by the instructional reading comprehension strategy that is Graphic Organizers (GOs). Most of the research findings revealed the use of GOs mostly approached as significant reading tool to achieve reading comprehension in EFL learning, and utilized as strategic way to problemsolving towards language learning intricacies. However, in this study, a researcher aimed to examine the use of Graphic Organizers as reading comprehension strategies for lifting the enhancement of communicative skills. GOs are worthily regarded as strategic methods consisting of the GOs' structures and their functions and the relationship between the GOs' patterned structures to their functions in purpose of making constructive and effective graphic models. The graphic patterns can contribute to EFL learners to represent their reading comprehension and show their frame of thinking. Thereby, how EFL learners can facilitate their English communication by adapting reading strategies, Graphic Organizers. Therefore, this research on the use of GOs for lifting the EFL/ESL learners' communication ability aims at answering the formulated problem, as in; in purpose of knowing how the Graphic Organizers (GOs) reading strategies promote language learners' communication ability or to describe on how the use of GOs reading strategies impact to the EFL learners' communicative skills. Therefore, in relation to the purpose of the conducted research that it can be carried out to have knowledge about the way of GOs' use in reading comprehension in purpose of promoting the EFL/ESL learners' communication ability.

Communication ability is now main goal of ELT when the theory of social rule which is to understand and produce the referential meaning and the social meaning. It is closelyrelated to the use of functional language teaching in need of developing communicative skills. One of the primacies of functionally-progressive language learning method, a blended learning, which is designed for integrating the traditional class interaction to the virtual learning. According to Ilyashenko et.al. (2019) who revealed the process of communicative skills development with a blended learning can produce mass of communicative competence, such as the ability to build social participation in the organizational enterprise, the ability to participate in the formation and maintenance of the corporate culture, etc. Moreover, the development of cognitive competence and communicative skills must have been carried out by encouraging the ESL learners to tend to the self-learning by providing them with an appropriate algorithm of conscious and independent work with information, and each of the 
stage must constantly be self-controlled (Tsoupikova, et al., 2019).

Vasquez et al., (2020) states that communicative skills as the result of successful intelligence where it is as a strategy of learning having significant effects to develop the analytical, creative, and practical intelligence in form of communicative skills. To develop communicative competence Larasati (2020) reveals by facilitating it through oral presentation performance. She moreover suggests that oral presentation tasks can contribute to self-regulated learning, decreasing learning anxiety, multimodal verbal learning styles used in learning the presentation materials. Presentation strategy plays an important role in the acquisition of knowledge and can be a part of assessment mode. In relation with the selfregulated learning, the use of presentation can contribute to the learners' awareness, coconstructing learning driven by teachers as imperative role in facilitating learners' development, and learning autonomy in autonomy-supportive fashion (Tsang, 2017). So the fruitfulness of oral presentation can lead a student-centered activities in purpose of increasing students' communicative skills, learning autonomy, learning opportunity to exposure (Brooks \& Wilson, 2015).

\section{LITERATURE REVIEW}

The relationship of the relevant sense of organs and the other sense of organs involve as in; the relationship of listening (sense of hearing) and speaking (kinesthetic) are active in the process of reading. The sense of sight's (reading) relationship with kinesthesis is active in writing. Writing activity represents the activity of reading that is, reading the schematic knowledge in mind in purpose of achieving the systematically-appropriate patterns of the writing. Then the sense of sight through reading the text is active in listening and finally the result of sense of hearing activity (listening) checked out via the sense of sight (Nan, 2018). As Nan's notion the presence of the integrated-relationship which belongs to the four language skills above suggesting the wholeness principles of system theory, in which they should integrally be conceived among the relationships. Whole language ability is a composed system, interwoven and integrated skills. The development of skills (reading and speaking) is according to and can trigger the development towards the other skills. Thus, what is called as a system theory. English teaching should be tended to the basic principles of a system theory by allowing the effective practice of the positive transfer made up between both reading and speaking. These skills must properly facilitate one other and the strength of the relationship of whole language ability and comprehensive English teaching and learning.

Guardado (2001) reported that information organizers can integrate language properties with contents of the text in ESL context. However, the use of GOs might have been misappropriate or might not get the maximum benefits in EFL reading comprehension hence the learners have yet to be taught on the variety of GOs' usage (Chien, 2012). Thereby, English teachers must guide alongside the teaching practice along with the use of GOs. Fortunately, the practice of significant GOs was proven to activate and develop EFL learners' analytic skills, reading skills, and writing skills (Kansizoglu, 2017). Interestingly, GOs can improve speaking skills and even creative skills. And also, those can assist EFL learners to focus on the important details / keywords, key concepts, and the relationship of the information structured (Aziz, et al., 2018). Varghese (2015), the development of oral 


\section{Dedi Aprianto \& Ikang Murapi}

language is dependent on English language learners' stagnant reading growth hence the difficulty appears in the area of reading comprehension skill. Thus oral language skill must have a significant role toward reading one. In the same way, reading has appropriatelysignificant effect to speaking. The reciprocal interrelationship of them shows that if the communicative language ability improves, so will improve the ability of comprehending the English text.

The literature on the potential effect of the extensive reading programmed at the university students in which it develops reading proficiency itself as well as the general language competence. Finally he suggested reading can be served as a springboard to (Ratchathani, 2016). The use of reading strategy can be regarded as a potential one to make English participants become involved in class-discussion and oral language confidence get better. Reading comprehension strategy has six components which can have significant effect toward oral language performance; automatic recognition skill, vocabulary and structural knowledge, formal discourse structure knowledge, content/world background knowledge, synthesis and evaluation skills/strategies, meta-cognitive knowledge and skill monitoring (Akbar, 2014).

In the significant impact of GOs in reading comprehension enhancement, Biria and Sharifi (2013) suggest that low-skilled readers of TOEFL reading comprehension test revealed the statistically-significant and effective impact by using graphic organizers as reading strategies. Moreover, GOs are properly regarded as the practical strategy to immediately engage EFL learners and readily link them with content and processes as they are independently working with their patterns in small groups or as a whole class (Hew et al., 2004). An active reader must have been categorized as a successful learner as she / he needs to consider the use of reading tool, what is so-called as graphic organizers has important role in reading comprehension activity. These strategies are valuably utilized as reading strategies in teaching EFL learners (Tobar and Moya, 2017).

Teaching a reading skill as a complex ability can be as important facts about reading instruction for English to provide effective instruction ways in reading comprehension learning. Thus, Samuel and Farstrup (2011) mention that effective teachers of reading comprehension assist their learners to develop the significant strategies to be active readers by teaching them how, when, and why to apply certain reading strategies. The use of graphic organizers (GOs) as reading strategies closely relates to what Mayer (2014) states on Cognitive Theory of Multimedia Learning (CTML), in which this theory is based on the three assumptions; learners' information channel processors, an auditory channel-a visual channel (pictorial), human's limited capacity of information processing, and learners actively engage in three generative cognitive processes to build the coherent mental model of the information the learners have been given where the three processes can be selecting the relevant information, organizing the information into a coherent cognitive structure, and integrating the information with the existing knowledge to form a coherent mental representation. In relation to Mayer's theory on information organizers to understand the document by organizing the relevant information into coherent representation, there is selfgenerated organizers which can be used to display alongside the document (generative processing). However, these types of information organizers can overload the cognitive 
capacity. So, the practice of self-graphic organizers performed more poorly than ready-made graphic organizers (Colliot and Jamet, 2018).

The frequency of reading activity can lead the wealth of the other language competence (speaking), as cited in Bright and McGregor (1970 in Akbar, 2014); where there is little reading, there will be little language learning. Reading skill is aimed to develop speech fluency as well as sentence accuracy. Moreover reading text is usually called as authentic language in form of a communicative purpose not in written production. In short, reading is the representation of sound decoding of semantic, grammatical, and morphological structures of a human language. The role of human communication in social contexts and a social notion of linguistic meaning as Davies and Pierse (2000 in Akbar, 2014) suggested on the significance of human language communication as "real success in English teaching and learning is when the learners can actually communicate in English inside and outside the classroom. The components of speaking ability consist of four components, as in; strategic competence that is, the communication should be according to the linguistics limitation. Grammatical competence comprises morphological, semantic, and syntactical structures of the words, phrases, and clauses. Sociolinguistics competence; the ability to communicative exposure where it represents the social contexts with certain norms, cultures, genders, professions, and needs. The last one, Discourse competence; the ability of articulating fluency along with sentence-accuracy (Akbar, 2014). It consists of producing the systematically-verbal utterances to make the meaning of language. According to Harmer (2001 in Mart, 2012) mentioned there are two major categories involve in speaking skill that is, accuracy and fluency. So, Mart (2018), knowledge of language and the practice of language skills are regarded as the two fundamental elements in an effective communication.

In teaching reading, the extra-instructional support must be met in order to get demanded English achievement. Reading passage must properly be done through reading comprehension strategies, due to the availability of the EFL learners' inability for comprehending the difficult and increasingly-sophisticated English text (Varghese, 2015). A language teacher must determine what sort of a reading comprehension strategy is properly and appropriately utilized in the practice of EFL/ESL language contexts. The instructional reading comprehension strategy is properly regarded as the extra-instrumental way to promote the linguistic competence that was forecasted. A reading skill is simply the interpretation of the written language production which is resulting the meaning gotten from the contextual resources (Mart, 2012). In the same way, a reading is the process of combining information from text as well as the reader's background knowledge for establishing meaning and goal of reading comprehension. So, it will be as follows (Nunan, 2013 in Mart, 2012):

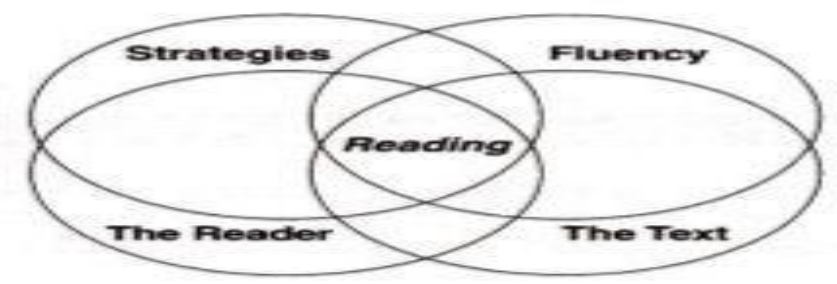

JELTL (Journal of English Language Teaching and Linguistics), 5(2), 2020 


\section{Dedi Aprianto \& Ikang Murapi}

Here, the researcher proposed the relationship of the whole elements of reading activity above; a reading is the entity of written text-embedded the message to the reader. Reading passage is composed of various types of the text cited from many sources. An ability of the reader to communicate the meaning of the text in fluency and accuracy.

GOs are regarded as the instrument of the presentation and modeling the information in various kinds of visual representation and even graphics in favor of getting the demanded EFL learning achievement. The functions of GOs are both to identify the most important concepts in a reading passage, and to omit the seductive details which can distract to find the main idea from the supporting ones of the text (Davoudi \& Yousefi, 2016). As Jiang \& Grabe, 2007), EFL teachers need to use GOs to facilitate reading comprehension process through visual representation of the key information of key concepts and the relationships between the concepts. So, the Graphic Organizers are regarded to have significant effects toward learners' improvement in comprehension, performance, and motivation in learning (Zaini et al., 2010). Thereby, GOs in reading comprehension development can make significant impact for understanding a text. GOs incorporate the advanced organizers of information and visualization into reading materials as the essence for teachers and learners. So, designing and even applying various reading strategies into second language (L2) classroom can have a substantial effect on the second language reading comprehension (Davoudi \& Yousefi, 2016).

In using GOs, EFL learners are aided to organize the contents of reading text so they are oriented to much better comprehend for information in form of facts, concepts, propositions, postulates, patterns, comparison and contradiction, cause-effect (causalrelation). McTighe (1992 in Sam D \& Rajan, 2013) revealed there are three main levels of using the GOs, namely before instruction; GOs are used to know and understand the levels of EFL learners in case of the sorts of contents of subject will be served. During instruction; GOs used for allowing the students to cognitively approach the contents of the subjects welldesigned hence they help them creatively and critically think of. The during instruction practice may lead the learners to construct the global mappings which are appropriatelypertinent to the EFL learners' learning styles. The after instruction; GOs both help the students make them as their techniques in EFL learning and help them to understand their improvement in case of comprehending the reading passages. In addition, the language learners mentioned that the prior knowledge belonging to them must be connected with what is learnt then they attempt to identify the relationship between them. This implies that GOs have successfully been done in EFL learning. The use of GOs in today's research received many attentions as they can be as alternatives in teaching-learning models. GOs have some functions, namely to clarify and organize important details within some stated categories, organize information in paragraphs, construct meaning, understand the context with association of learners' prior knowledge, and identify conceptual and even perceptual errors in reading activities (Sam D. \& Rajan, 2013).

There are 6 Graphic Organizers' patterns; hierarchical, conceptual, sequential, evaluative, relational, and cyclical (Zaini et al., 2010), and the categories of Graphic Organizers' structures are webbing, concept-mapping, matrices, and flow-chart. Just the opposite the categories of their functions are describing, comparing-contrasting, sequencing, 
classifying, cause-effect (causal relationship), and decision-making. Therefore such a research on the use of Graphic Organizers reading comprehension strategies in favor of lifting the EFL learners' communication ability aims to answer the problems formulated. Zaini, et al. ( 2010), Gil-Garcia and Villegas (2003) shared the types of graphic organizers; description/simple listing, temporal sequence, definition-example, comparison-contrast, cause-effect, and problem-solution. In addition, Chien (2012), there are also several GOs which can be utilized; conceptual development charts, Venn diagrams, and T-charts. So, the use of GOs in classroom practice is expected to have contributed to EFL learners to understand the academic language and content knowledge. The use of GOs through direct strategies (cognitive and compensation strategies) and indirect strategies (metacognitive, affective, and social strategies) can facilitate language learning in many ways as well as endeavor to reduce monotony situation of learning. GOs also can assist the learners to become more confident (Aziz, et al., 2018).

\section{RESEARCH METHODS}

The research method is the well-structured framework which was built in purpose of planning the research under control. It was designed to conduct the process of decisionmaking before situation arisen in which the decision had to be carried out. Eventually this research was constructed under planning, justified decision-making and deliberate anticipation to control (Blaikie, 2000). The research was a descriptive qualitative to depict on how EFL learners facilitated with the Graphic Organizers (GOs) is as language learning strategies to promote an English proficiency. Thus, this was technically carried out by determining the participants, instruments, data collection strategies and data analysis strategies.

\subsection{Participants}

The participants of the research were the sophomore university EFL students in computer science department, Bumigora University, Indonesia. The total participants of the research were 44 EFL learners hence those were taken through a purposive sampling. Those were categorized into 4 groups of English proficiency level; Elementary level (A2), Intermediate level (B1), Upper-intermediate (B2), Advanced level (C1).

\subsection{Instruments}

Data Collection was done by employing a non-participant observation in which it was employed by attending the class as an observer (key instrument). Then this must have been embedded with so-called as semi structured observation sheet along with descriptive fieldnote and reflective field-note. Additionally, this technique was supported by the use of video-recording with a mini camera oriented to cross-check the gathered data through the observation.

\subsection{Data Analysis}

Data analysis process was oriented to get conclusive on the final result of the study, in favor of answering the research question. The data of the research was systematically analyzed and constructed to infer the meaning of wholeness of both the observation's data and interview's data. Such data was inductively analyzed and interpreted hence it is an 


\section{Dedi Aprianto \& Ikang Murapi}

ethnographic research. The data was analyzed by using Miles and Huberman's (1994), an Interactive Analysis Model; data reduction, displaying, and conclusion drawing/verification. This was analyzed through the informal analysis (field-based analysis) and the formal analysis (out-field-based analysis).

The reduced data was then coded and clustered into particular relevant data and certain groups of data. Then, displaying the data by organizing it into compressed assembly of the organized information; by presenting the data into particular compressed assembly in form of tables in order to facilitate to analyze and even draw a conclusion. Finally, conclusion / verification is the process of taking inferences or interpretation interactively from the beginning to the ends of data collection by reflecting the research problems on how the use of GOs as learning strategy towards a speaking performance. The interpretation was done to explore the meaning of what was going on, such as classroom regularities, social interaction, productivity, creativity, psychological situation of EFL learners, possible configuration, and cause-effect relationship. The last is verification by cross-checking the researcher's mind / conclusion.

\section{FINDINGS}

This study found four levels of English proficiency belonging to the current study's participants that is, of 44 total students were categorized into elementary (20.4\%), intermediate $(22.8 \%)$, upper intermediate $(34.0 \%)$, and advance $(22.8 \%)$. According to the displayed data of the whole number of the participants, it revealed that upper intermediate level of English proficiency (B2) indicates the dominance consisting of 34.0\%. In relation to how the use of Graphic Organizers (GOs) as reading comprehension strategies in favor of fostering EFL learners' oral exposure. The findings suggest on how the use of Graphic Organizers (GOs) as strategies for increasing the development of communicative ability in class presentation, as in:

\subsection{Elementary EFL learners level (A2)}

EFL learners of an elementary level which are graded a basic level of language learning proficiency can be categorized as non-competent or passive speakers. Thus, most of them do not have a good English proficiency to expose the information they stored, studied, and analyzed. In the context of classroom participation, those engaged and initiated to utilize GOs to present the reading comprehension in form of conceptually-framed details under scientific ICT discourse. Also, they designed their materials made-up in power-points media by applying varying Graphic Organizers' structures and functions, such as webbing, concept-mapping, matrix, and flow-chart.

To answer to what extent GOs improves communication ability through the practices of graphic organizer strategies in presentation duty revealed the findings of the research. There are three language learning intricacies discovered, as in the presence of the incapability of English speaking type one, the incapability of English exposure type two, and the misunderstanding of using GOs. According to the data of the observation analyzed suggests that linguistic problems faced by the cooperative intermediate learners by showing their communication problems caused by less vocabularies and speaking practices, the psychological problems, learners' anxiety as well EFL in which the learners tend to utilize 
conceptually-made details in form of bulk of notes by reading all the information stored, analyzed, and understood. The psychological problems which can be studied is that the EFL learners felt so anxious to expose the academic task in a class presentation. Also, the portrayal of class presentation was depicted improperly-incomplete, unstructured and unclear ways.

The non-corporative learners got the strong language problems because they attempted to disobey as well as not be aware to the language learning program. The indicators which can be categorized as the linguistic problems, namely EFL students got main problems to use the target language because of poor vocabulary, EFL students have strong language proficiency intricacies, and EFL students tried to disobey the agreed language tasks. On the other hands, the psychological problems are that learners were observed as being not confident to perform GOs as a learning strategy and Learners were not so aware of doing a class task. The last is misunderstanding of using GOs in which they could not adapt the GOs' structures and their functions. In fact, they did not make the presentation media properly. With the intricacies found, those elementary EFL learners endeavored to expose their reading tasks in the class presentation by making use their own technological devices, like smart phones, tablets, etc. storing bulk of information for facilitating their topic description, but they failed to enable to increase their oral presentation. In fact, learners have used the devices with bulk of detailed information relating to the given topic in improper way, in which they just read the written information on the devices without making the clear what is revealed on. And the psychological problem in which EFL students felt that they did not rely on themselves to display as well as to show their own reading understanding through GOs

\subsection{Intermediate EFL learners level (B1)}

The general description of language proficiency's indication that corresponds to the intermediate level (B1) shows that the use of GO's patterns which are regarded as significant language strategies to induce the pre-steeps to contribute towards English performance demanded, as in:

\section{No. Attributes}

\begin{tabular}{l|l} 
\\
$1 . \quad \begin{array}{l}\text { Effective } \\
\text { Learning } \\
\text { Interest } \\
\text { (Soft Skills) }\end{array}$
\end{tabular}

\begin{tabular}{ll}
\hline $\begin{array}{l}\text { Linguistic } \\
\text { gains }\end{array}$ & $\begin{array}{l}\text { Non-linguistic } \\
\text { gains }\end{array}$ \\
\hline $\begin{array}{l}\text { Pre-steep of } \\
\text { active learning } \\
\text { (No linguistic } \\
\text { enhancement) }\end{array}$ & $\begin{array}{l}\text { Self-motivation, } \\
\text { self-confidence \& } \\
\text { dissanxiousness }\end{array}$ \\
\hline
\end{tabular}

- $\mathrm{EF}$

- EFL students used GOs' class presentation strategy as a pre-steep to trigger or induce English learning enhancement.

- EFL learners considered that GOs as the recommended language learning media.
Linguistic gains; $\quad$ A $\begin{array}{ll}\text { EFL learning through class } & \text { questioning } \\ \text { presentation was } & \text { technique }\end{array}$ interactively undertaken. (1)

\section{Strategies}

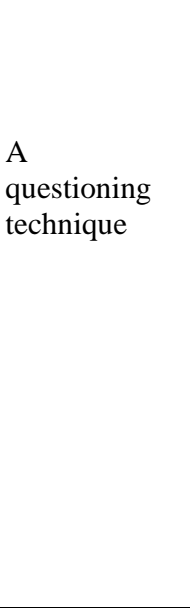

JELTL (Journal of English Language Teaching and Linguistics), 5(2), 2020 


\begin{tabular}{|l|l|}
\hline Psychological gains; \\
EFL students could be \\
depicted to have \\
participated and to have \\
been motivated to do class \\
engagement in presentation \\
task. \\
$\begin{array}{ll}\text { EFL students have looked } \\
\text { to cast off the barriers in } \\
\text { class activities. }\end{array}$ \\
\hline
\end{tabular}

It suggests GOs' patterns which are designed as learning media to showcase the information gathered in form of class presentation via power-point slides can worthily be regarded as recommended media. Instead most of the intermediate students endeavored to delineate the information on the topic with bulk of notes, but they can seemingly be guided by effectively scaffolding them through a questioning technique. With the fundamental shortages belonging to intermediate EFL learners, the use of a questioning technique can be utilized in form of the guided-Graphic Organizers' models which can contribute to making sure their confidence and decreasing their language anxiety (psychological gain) so these could seemingly begin to improve upon their low English proficiency (linguistic gain). Thus, the practice of GOs along with the instructional teachers' guidance that can encourage intermediate EFL learners' interest and even great efforts is predicted to enable them to effectively communicate their own ideas.

Additionally, another important psychological aspect discovered was the presence of intermediate learners' awareness for utilizing the recommended or free-chosen Graphic Organizers' patterns (structures and functions). The psychological aspect belonging to every learner can motivate to study more and endeavor to communicate the studied language. Eventually, it can softly decrease language production anxiety. In sum, the availability of awareness has put an important role to enable the intermediate EFL learners to use the language. The class presentation held through GOs strategies is regarded as the challenging opportunity to upgrade soft awareness for communicating the ideas.

\subsection{Upper-Intermediate EFL Learners (B2)}

In this part, there are varied models of GOs' usage discovered in the observation phase.

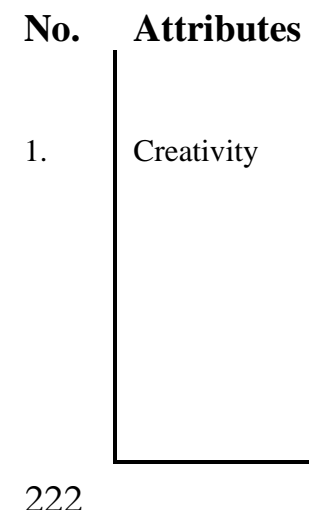

\begin{tabular}{ll} 
Learning Achievement \\
\hline $\begin{array}{l}\text { Linguistic } \\
\text { gains }\end{array}$ & $\begin{array}{l}\text { Psychological } \\
\text { gains }\end{array}$ \\
Communicati & Being \\
ve skills \& & motivated \& \\
Intelligible & being more \\
class- & confident \\
presentation &
\end{tabular}

$\begin{array}{ll}\text { Indicators } & \text { Strategies } \\ \begin{array}{ll}\text { Linguistic gains; } & \text { Re-writing } \\ \text { technique }\end{array} \\ \begin{array}{l}\text { EFL students } \\ \text { creatively combined } \\ \text { patterned GOs' with } \\ \text { their own models of } \\ \text { information organizers }\end{array} \\ \text { - EFL students } \\ \text { intentionally used the } \\ \text { traditional ways by }\end{array}$


The Graphic Organizers (GOs) in the Development of Communicative Skills

\begin{tabular}{|c|c|c|c|c|c|}
\hline & & & & $\begin{array}{l}\text { describing the concept } \\
\text { of reading text with re- } \\
\text { writing on the } \\
\text { whiteboard in form of } \\
\text { self-GOs. } \\
\text { Psychological gains; } \\
\text { - EFL students are fond } \\
\text { to make their } \\
\text { presentation innovative } \\
\text { and make something } \\
\text { novel to discuss } \\
\text { EFL students felt so } \\
\text { sure to perform or to } \\
\text { share a novel way in } \\
\text { using given strategies. }\end{array}$ & \\
\hline 2. & $\begin{array}{l}\text { Comprehensive } \\
\text { Presentation } \\
\text { Method }\end{array}$ & $\begin{array}{l}\text { Comprehensi } \\
\text { ve } \\
\text { understanding } \\
\& \text { Detailed } \\
\text { information }\end{array}$ & - & $\begin{array}{l}\text { Linguistic gains; } \\
\text { - EFL students tend to } \\
\text { elaborate all parts of } \\
\text { the article, then they } \\
\text { go to the GOs as a } \\
\text { reviewer }\end{array}$ & $\begin{array}{l}\text { Chronological } \\
\text { presentation }\end{array}$ \\
\hline 3. & Productivity & $\begin{array}{l}\text { Meaningful } \\
\text { language } \\
\text { exposure \& } \\
\text { language } \\
\text { development }\end{array}$ & $\begin{array}{l}\text { Being } \\
\text { motivated \& } \\
\text { being confident }\end{array}$ & $\begin{array}{l}\text { Linguistic gains; } \\
\text { - EFL students could } \\
\text { develop and/or } \\
\text { increase their language } \\
\text { performance which } \\
\text { can be compared with } \\
\text { the their previous poor } \\
\text { language proficiency. } \\
\text { Psychological gains; } \\
\text { - EFL students are } \\
\text { encouraged to be } \\
\text { active as well as } \\
\text { productive in a } \\
\text { language learning } \\
\text { enhancement through } \\
\text { GOs' practice. }\end{array}$ & $\begin{array}{l}\text { A note-taking } \\
\text { technique }\end{array}$ \\
\hline
\end{tabular}

The Graphic Organizers-based learning strategies yielded the multimodal of EFL learning techniques scientifically able to be considered. The GOs' strategies which were employed by EFL upper intermediate indicate the availability of EFL learning's techniques which contribute to language performance advancement. With the use of GOs-based class presentation, this strategy shows a significant role as a language learning media allowing learners for producing creativity. The creativeness can be observed through the combination between electric power-points presentation with manually-traditional presentation written on whiteboard. This technique was done by collaborating the prepared slides with the prepared notes which will be re-written on the whiteboard, while they are endeavoring to elaborate the concept of their reading comprehension they understood. Thus, this is termed as a rewriting technique. The creativeness can be represented from both linguistic advantages and psychological advantages which cane seen in the table above. The second technique employed was a chronological overview where it was mostly performed by showcasing the 


\title{
Dedi Aprianto \& Ikang Murapi
}

overall parts of the topic given respectively in varying forms of linguistic properties (comprehensive presentation methods), such as; phrases, sub-clauses, sentences, or a group of sentences. The EFL learners would rather utilize the bulk of phrases and a group of sentences to represent their own reading comprehension than use dominant graphic organizer models. Thereby, less of the graphic organizer usage indicates a little impact towards learners' language performance. In sum, this pattern was carried by focusing the bulk of sentences then the learners go utilizing the GOs at the rest of the class presentation time for emphasizing the previous information on the reading passage given. So, GOs are used as reviewers.

The third strategy undertaken by the GOs' users having basic speaking skills is notetaking technique where they benefit the GOs to foster spoken skills. Furthermore, the use of GOs is regarded to help invoking learners' interest to do oral communication in a class presentation. GOs can increase the EFL learners' productivity which can be observed and compared with the previous English performance. This technique was done by viewing the main ideas of the subjects, and then those main ideas can be as guidelines to do the presentation in sequent and comprehensive way.

\subsection{Advanced EFL Learners (C1)}

Accordingly, the research findings show that the advanced students might have used the experiential learning strategies indicated by most of them explained their topics by reflecting their own life experiences within academic, social, technological facts created in lives. The findings can be presented in these descriptive overviews. These scientific facts obtained from the observation carried out suggest in the table alongside the description below;

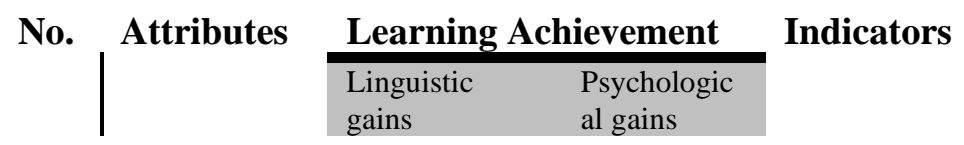

\author{
Strategies
}


The Graphic Organizers (GOs) in the Development of Communicative Skills

\begin{tabular}{|c|c|c|c|c|c|}
\hline 1. & $\begin{array}{ll}\text { Authentic } & \\
\text { learning \& } \\
\text { simplicity of } \\
\text { learning }\end{array}$ & $\begin{array}{l}\text { Authentic } \\
\text { speaking, } \\
\text { contextual } \\
\text { vocabulary \& } \\
\text { advancement } \\
\text { of language } \\
\text { exposure }\end{array}$ & $\begin{array}{l}\text { Being } \\
\text { motivate, } \\
\text { enjoyable \& } \\
\text { aware }\end{array}$ & $\begin{array}{l}\text { Linguistic gains; } \\
\text { - EFL students tend to use to } \\
\text { study the existed facts- } \\
\text { based sources. } \\
\text { - EFL students might have } \\
\text { used their own experiences } \\
\text { to correlate with the topics. } \\
\text { Psychological gains; } \\
\text { - EFL students might have } \\
\text { been motivated in using the } \\
\text { authentic learning sources. } \\
\text { - EFL students could be } \\
\text { aware of the importance of } \\
\text { the authenticity of language } \\
\text { learning. }\end{array}$ & $\begin{array}{l}\text { Experiential } \\
\text { learning strategy }\end{array}$ \\
\hline 2. & $\begin{array}{l}\text { Interest-based } \\
\text { presentation }\end{array}$ & $\begin{array}{l}\text { Speaking } \\
\text { performance, } \\
\text { specific } \\
\text { language } \\
\text { purposes, } \\
\text { meaningful } \\
\text { language } \\
\text { properties \& } \\
\text { specific } \\
\text { vocabularies }\end{array}$ & $\begin{array}{l}\text { Interesting } \\
\& \text { being } \\
\text { motivated }\end{array}$ & $\begin{array}{l}\text { Linguistic gains; } \\
\text { - EFL learners often use the } \\
\text { topics correlating to specific } \\
\text { interests } \\
\text { Psychological gains; } \\
\text { - EFL students would prefer } \\
\text { study on the topics related } \\
\text { to their own interests. } \\
\text { - EFL students are fond of } \\
\text { improving their speaking } \\
\text { performance through } \\
\text { purposive topics and } \\
\text { interesting information. }\end{array}$ & $\begin{array}{l}\text { (Needs-Based } \\
\text { Strategy) }\end{array}$ \\
\hline 3. & $\begin{array}{l}\text { Constructive } \\
\text { learning }\end{array}$ & $\begin{array}{l}\text { Dynamic } \\
\text { language } \\
\text { learning, } \\
\text { interactive } \\
\text { learning(social } \\
\text { participation), } \\
\text { linguistic } \\
\text { creativity \& } \\
\text { language } \\
\text { productivity }\end{array}$ & $\begin{array}{l}\text { Being } \\
\text { motivated \& } \\
\text { more } \\
\text { interesting }\end{array}$ & $\begin{array}{l}\text { Linguistic gains; } \\
\text { - EFL students have a good } \\
\text { English proficiency. } \\
\text { - Advance EFL students } \\
\text { might have participated } \\
\text { interactively. } \\
\text { - Advanced EFL students } \\
\text { mastered the concept of } \\
\text { GOs and the topics. }\end{array}$ & $\begin{array}{l}\text { understanding of } \\
\text { GOs concept } \\
\text { and the topic }\end{array}$ \\
\hline
\end{tabular}

Based on the table above there are three important findings discovered in the advanced ESL learners' practices of the graphic organizers, as in:

\subsubsection{Experiences-Associated Learning}

An effective model employed to do an English communication task in form of class presentation is carried out by reflecting the experiences existed. This model is so-called as an employing prediction by thinking the relevant experience back associating with the topic being studied. The advanced language learners frequently tend to describe the problems related to the topic in simple way, as in easy vocabularies, the choice of simple dictions, and the contextual examples used as the additional details. Instead this model also is driven by comprehensively elaborating the subject in form of the use of Graphic Organizers strategies. 


\section{Dedi Aprianto \& Ikang Murapi}

Furthermore, the use of GOs could have been beneficial for EFL learners where they felt motivated and enjoyable to utilize these strategies via the particular GOs' structure, matrix. Thereby this can contribute to the learners' awareness to do communicative activities in social engagement, and the intermediate learners do, too. However, the positive awareness belonging to the advanced learners were identified to increase their good English to much better than the intermediate learners do.

\subsubsection{Pre-determined Interesting Topics-Based Selection}

EFL learners having a specific interest on the subject matter can lead to increasing benefits to develop their English performance. It is closely-related to teaching English for special purposes either academic purposes or professional purposes. However, ESP, a subject of EFL or ESL curriculum programs, is designed for both university students and employment programs. The way learners present the subject of the particular interesting topic is via self-selection strategy by structurally-respective sequencing the main problem into subsets of the problem, then they endeavored to clarify the categorized subsets of the problem in detailed and simple way. Another way the advanced learners use through this kind of pattern is by using naturally-easy language along with no sophisticated linguistic properties. The pattern of self-selected topics is mostly utilized by exploring the problems with specific vocabularies and specific language expressions to the topics chosen and even mastering the topic can significantly affect the advanced language learners' oral exposure. In sum, self-selected topics can impact the way the advanced learners to use GOs so they must decide what the appropriate topic that can make the class presentation effective and interesting.

It is referenced to particular skills needed and given to achieve the specific aims. Therefore, the pre-determined interesting topics-based learners' self-selection might have had strong impact to easily describe, make sequence, and classify the problems under selfselected topics which are based on the specific interest or special demands. Self-selected topics are regarded as a successful way to promote English proficiency hence this pattern of topic selection can pronely be used to correlate the problem being discussed to their own authentic interests. This is also called as self needs-oriented strategy.

\subsubsection{Comprehensive Understanding of Graphic Organizers Concept and the Topics (GOs and Topics-Based Comprehension)}

The advanced learners used GOs effectively and easily by understanding more on the concept of GOs and the topics as a presentation subject and those can pronely be effective by having a good English proficiency background. The advanced English learners have just demonstrated a simple matrix structure to represent their own reading comprehension under certain topics, yet they have done well. Additionally, they utilized symbols, group of words or combination of sentences along with the sophisticated and structured ways to complete the matrix used. They mastered how to depict, sequence, and make relationship amongst the concepts they demonstrated. Furthermore, the comprehension of GOs' concepts and even the topics of class presentation makes the advanced language learners feel more dynamic, interactive, and creative in terms of doing a class presentation task. Therefore, the use of 
graphic organizers towards the advanced English learners has put significantly-positive impacts to build up the socially-interactive class participation through questioning-answering strategy. Thus, the advanced language learners using these strategies of communicative class presentation might have given strong learning outcomes in form of effective class presentation as they endeavored to take the opportunity to increase language performance.

\section{DISCUSSION}

The research question on to what extent the use of GOs can improve speaking ability for the university students of the four language learning proficiency levels; elementary, intermediate, upper-intermediate, and advanced learners. Accordingly, the practices of GOs are regarded to have contributed to the positive impacts towards both linguistic gains and non-linguistic gains (psychological advantages) in ELL (English Language Learning). Having classified the whole data of the qualitative details obtained from the descriptive and reflective observations, the researcher found the multimodal attributes of English learning employed in the use of graphic organizers as learning strategies. EFL learners of the elementary levels (A2) met with intricacies in exposing oral language skills in which the basic problems let them enable to have limitation on oral proficiency which is caused by speaking frequency, fewer amounts of vocabularies, lack of confidence, and lack of speaking interest. Heriansyah (2012), there are two general language problems encountered, that is linguistic and non-linguistic intricacies. Where Al Hosni (2014) revealed the communication difficulties faced by the young learners brought on by linguistic difficulties, the inherent use of mother tongue, and the inhibition to speak up.

The other learners' presentation problems transpired in the process of class presentation can be identified, as in pre-determined preparation is ignored by the presenting learners, so those have intricacies to show the topic they had. In relation to the ignored preparation could be depicted within not preparing the topics of class presentation, not making the presentation media (power-points), and doing class presentation in improper model which does not adapt to what is agreed. So, EFL learners having low English proficiency can be depicted through two categories that is to say, those having low English proficiency have interest to endeavor to use oral language even they still have difficulties to expose it. The latter category having low English proficiency was not only uninterested in using spoken English, but also having bad English performance.

Another problem discovered in elementary English learners that most of them do not understand to incorporate the concept of GOs between the patterned structures with their functions. Therefore, the problems are identified not only the problematic English proficiency, but an ability to conceive the concept of GOs as well. The elementary English learners in ELT (A2) are found to have had ineffectiveness to use the given GOs as their strategies to do class presentation, as the communication inability is caused by less speaking frequency, less vocabulary, and lack of confidence. Also, they had technical problems that they did not prepare the presentation instruments, such as power-points' slides, could not do properly their presentation. Therefore, those psychological problems and technical problems led the negative impacts towards elementary English level learners' interest.

Instead, the intermediate English learners (B1) using the GOs in class presentation depict that the use of GOs could worthily be as recommended media for effectively enabling 


\section{Dedi Aprianto \& Ikang Murapi}

to contribute to stimulate the intermediate learners' confidence, to decrease language anxiety, and to induce self-awareness. Basically, the intermediate learners had fundamental shortages in term of using the effective target language. However, they attempted to be effectively engaging to use the Graphic Organizers by following certain technique, namely the use of questioning technique. This technique was carried out by in form of the guidedGraphic Organizers' (gGOs) models which may lead to stimulate their confidence and to decrease their language anxiety so these could seemingly begin to improve upon their low English proficiency. All in all, the use of GOs along with the instruction's scaffolding guidance which can encourage the intermediate EFL learners' interest and great efforts is predicted to enable them to effectively communicate their own ideas.

The GOs employed by the upper-intermediate learners can produce creativity, in which those can be combined with manually-traditional ways of class presentation, as in; the first pattern is done by rewriting the prepared structured information in form of GOs to manual way, namely writing on the white board. So, it is called as re-writing technique. In relation with the presence of creativity in ELT, creativity has a significant role on boosting English oral competency along with the use of learner-centered and task-led communicative techniques conducted through both individual performance, and team work (Minasyan, 2016). In addition, Avila (2015) put forward creative ELT activities are designed to improve the oral and written language having a lack of interest. The second pattern is the chronological overview, in which GOs is used as a reviewer after having elaborated the overall details in form of phrases, sentences, and paragraphs. The third pattern is note-taking technique. The last pattern is done by reviewing the prepared notes as guidelines to elaborate the problems of class presentation.

The use of Graphic Organizers-based presentation technique leads the great advancement towards advanced learners having tasks in class presentation. The criteria of advanced English level cover the creativity, productivity, a few accuracy, and fluency. Of the overall components categorizing towards advanced level, some of the respondents of this study acquired several the so-called components of advanced English proficiency level. Instead the recommended aspects of language considered to be advanced EFL learners under this scientific study are not only the quality of fluency, but also the quality of English accuracy. The advanced language learners showing the ways they employ the Graphic Organizers in a class presentation task, namely experiences-associated learning by correlating with what they have done in form the existing knowledge (authentic learning), topic-based self-selection, and the comprehension of Graphic Organizers' structures and functions as well as the comprehensive understanding of the reading passages.

The significant facts-based language learning experiences can lead to English advancement. To conclude, the manifestation of the use of new trends, the graphic organizer strategies employed by advanced EFL learners, can have contributed to produce a concept of experiential learning, the well-determined topics-based self-choices, and comprehensive understanding of GOs and topics. A concept of experiential learning is supported by a theory stated as a holistic model of the learning process and as a multilinear model of adult development based on what one knows about how people learn, grow, and develop 
consistently. It is also defined as the process "whereby knowledge is created through the transformation of experience (Sternberg \& Zhang, 2000).

Throughout the findings of the current study, language learning must have principally been designed in term of the perspective of both curriculum-materials development and methodologies. The study suggests graphic organizers which are so long regarded as reading strategy delineate successful one, but researcher attempted to design the same strategy in make the development of English oral exposure up. As result, GOs as speaking learning strategies can be seen, as in:

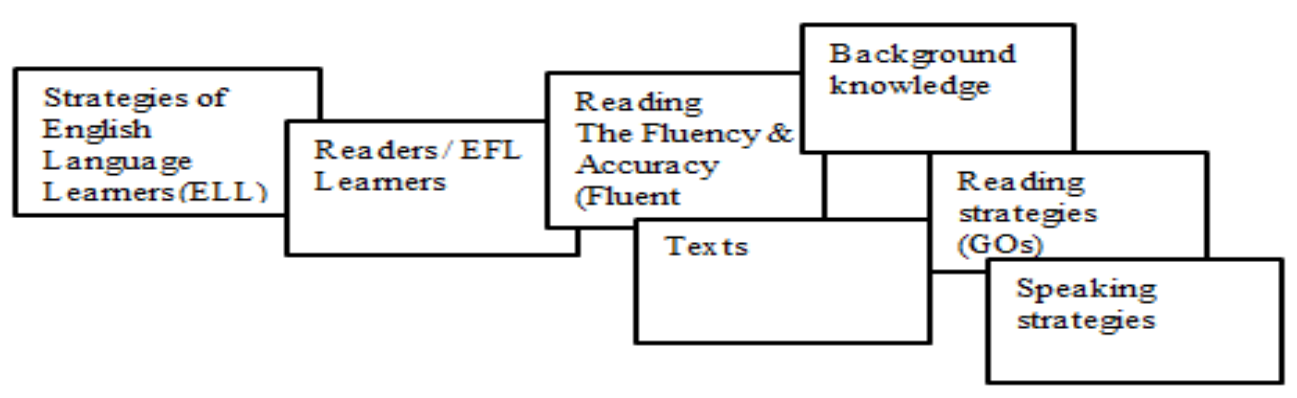

\section{CONCLUSION}

Speaking and reading have particular roles in language skills development, that is to say that speaking is termed as productive skill and reading is called as receptive skill. The divergent skill roles have led to correlate in order to scaffold each other. In this study, a speaking skill necessarily imports the importance of reading comprehension's strategies as the effective reading trend, Graphic Organizers (GOs). The reading instruments used as presentation strategies which are modeling the information of reading contents into varying visual representations, such as graphics, tables, matrixes, etc. These strategies are aimed at translating the linear form of text into visualization of structures of the text in order to facilitate EFL learners' understanding towards the complicated texts. Eventually, the study suggest the results of the importance of GOs positively lead English proficiency towards different English learners levels; elementary, intermediate, upper-intermediate, and advance levels. All in all, GOs' reading comprehension strategies performed in English class presentation are regarded to have positively impacted towards EFL learners within both advancement of linguistic performances and non-linguistic gains for each different English proficiency levels.

\section{REFERENCES}

Akbar, F. (2014). The Role of Reading in Improving Speaking Skills in the Context of Teaching English as a Foreign Language. International Journal of English Language and Translation Studies, 2 (4), 92-98

Al Hosni, S. (2014). Speaking Difficulties Encountered by Young Learners. International Journal of Studies in English Language and Literature (IJSELL), Vol. 2 (6), 22-30. 


\section{Dedi Aprianto \& Ikang Murapi}

Avila, H.A. (2015). Creativity in the English Class: Activities to Promote EFL Learning. HOW, Vol. 22 (2), 91-103.

Aziz, A. Z. A. (2018). Exploring the Use of Direct and Indirect Learning Strategies on Graphic Organizers in the ESL Classroom. $4^{\text {th }}$ International Conference ILANNS, 30-38

Biria, R. \& Sharifi, M.M. (2013). Graphic Organizers and Reading Comprehension Ability: Evidence from Iranian EFL University Students. Sino-US English Teaching, 10 (5), 358-365

Blaikie, N. (2000). Designing Social Research: The Logic Anticipation. Cambridge: Polity Press

Brooks, G \& Wilson, J. (2014). Using Oral Presentations to Improve Students' English Language Skills. Kwanzaa Gakuin University Humanities Review, Vol. 19, 199-212.

Chien, C. W. (2012). Use of Graphic Organizers in a Language Teaching Professional Development. English Language Teaching, 5 (1), 49-57

Colliot, T. \& Jamet, E. (2018). Does Self-generating a Graphic Organizer while Reading Improve Students' Learning? Computers \& Education, 126, 13-22

Davoudi, M. \& Yousefi, D. (2016). The Effect of Graphic Organizer Instruction on Reading Comprehension Improvement of EFL Learners in Iran. International Conference on Literature and Linguistics (irLIT). 1-14

Gil-Garcia, A. \& Villegas, J. (2003). Engaging Minds, Enhancing Comprehension and Constructing Knowledge through Visual Representations. Paper presented at a Conference on World Association for Case Method Research and Application. Retrieved from http://www.eric.ed.gov/PDFS/ED480131.pdf

Guardado, M. (2001). The Facilitative Effect of Graphic Organizers in TESL. Theoretikos: la revsita electronica de la UFG VI (1). Retrieved from http://www.ufg.edu.SV/ufg/theoretikos/enero2001/aportesoI.htm

Heriansyah, H. (2012). Speaking Problems Faced by the English Department Students of Syiah Kuala University. Lingua Didaktika, Vol. 6 (1), 37-44.

Hew, K. et al., (2004). The Eight Events of Instruction: An Instructional Method Based on the Constructivism Paradigm. In C. Crawford, N et al., Proceedings of the Society for Information Technology and Teacher Education. Association for the Advancement of Computing in Education, 4110-4115

Ilyashenko, L.K. et al., (2019). Development of Communicative Competencies of Students in the Context of Blended Learning. Amazonia Investiga, Vol. 8 (18), 313-322.

Jiang, X. \& Grabe, W. (2007). Graphic Organizers in Reading Instruction: Research Findings and Issues. Reading in a Foreign Language, 24 (1), 84-105

Kansizoglu, H.B. (2017). The Effect of Graphic Organizers on Language Teaching and Learning Areas: A Meta-Analysis Study Education and Science, 42 (191), 139-164

Larasati, R.H. (2020). Self-Regulated Learning on Students' Oral Presentation Performance in Academic Speaking Class. RETAIN (Research on English Language Teaching in Indonesia), Vol. 8 (4), 128-138.

Mart, C.T., (2012). Developing Speaking Skills through Reading. International Journal of English Linguistics, 2 (6), 91-96 
Mayer, R.E. (2014). Cognitive Theory of Multimedia Learning. In Mayer, R.E (Ed.). The Cambridge Handbook of Multimedia Learning: Second Edition. New York: Cambridge University Press.

Minasyan, E. T. (2016). Developing Oral Proficiency via Creativity in EFL Classroom. Plekhanov Russian Academy of Economics, 1-3.

Nan, C. (2018). Implications of Interrelationship among Four Language Skills for Higher School English Teaching. Journal of Language Teaching and Research, 9 (2), 418-423

Sam, D.P and Rajan, P. (2013). Using Graphic Organizers to Improve Reading Comprehension Skills for Middle School ESL Students. English Language Teaching, 6 (2), 155-170

Samuel, S.J. \& Farstrup, A. E. (2011). What Research has to say about Reading Instruction. International Reading Association, 51-75

Sternberg, R.J. \& Zhang, L.F. (2000). Perspectives on Cognitive, Learning, and Thinking Styles. NJ: Lawrence Erlbaum.

Tobar, M.C.S. \& Moya, N.P.G.(2017). Graphic Organizers as a Reading Strategy: Research Findings and Issues. Revista Publicando, 4 (12), 247-258

Tsang, A. (2017). Enhancing Learners' Awareness of Oral Presentation (Delivery) Skills in the Context of Self-Regulated Learning. Active learning in higher education, 1-12.

Tsoupikova, H. et al., (2019). Developing Students' Cognitive and Communicative Skills When Learning Foreign Languages. SHS Web of Conferences 69, CILDIAH. https://doi.org/10.1051/shsconf/20196900037

Varghese, J.L. (2015). Relationship between Oral Language and Reading Comprehension for English Learners: A Systematic Review. School of Education Student Captone Thesis and Dissertations, 132.https://digitalcommons.hamline.edu/hse_all/132.1-91

Vasquez, B.J.S. et al., (2020). Communicative Skills as a result of Successful Intelligence. Psychology and Education, Vol. 57 (1), 62-69.

Villas, M. (2016). Extensive Reading: Its Effects to Learners' General Language Competence. The Online Journal of New Horizons in Education, 6 (4), 80-85

Zaini, D.P et al., (2010). The Effect of Graphic Organize on Students' Learning in School. Malaysian Journal of Educational Technology, 10 (1), 17-23 